\title{
»Communal Labour « - another technique of acquisition of manpower required for administrative tasks in Cameroon?
}

\author{
By E.H. Ngwa Nfobin, Dschang/Cameroon
}

\section{Introduction}

The State which is a technique of social organisation that originated from Europe was born to cater for the basic needs of its citizens. To this effect, the modes of acquisition of the means necessary to achieve its ends, have in recent years increased in proportion to the targets it set for itself. The means at its disposal have multiplied manifold as it shifted from its traditional role of a panoplied policeman to a provider of basic goods and services. Law students in French-speaking countries studied the procedures by which the state acquired the means necessary for the accomplishment of the mission assigned to it in droit administratif approfondi or droit administratif spécial. Because we made the choice from the beginning, we are going to restrict ourselves to the study of a particular aspect of these means - manpower.

Cameroon droit administratif spécial states the means by which the State acquires the manpower necessary for the accomplishment of its mission. They are called the agents of the administration. They can be studied under two categories - civil servants (fonctionnaires) who are permanent, and contract officers (agents contractuels) who may be temporary. Both serve the administration during normal periods. Civil servants may be recruited through a competitive examination or by appointment. Meanwhile contract officers are parties to contracts with the administration. To meet an emergency, the state may resort to the procedure of requisitioning. Law $\mathrm{N}^{\circ} 68 / \mathrm{LF} / 4$ of 15 June 1968 defines requisition as "an act of public authority whereby some civil or military body impose the performance of certain services on some natural person or corporate body under conditions strictly defined by the law". Labour conscripts (les requis) are forced collaborators of the administration (les collaborateurs forcés de l'administration). Besides these, there are benevolent collaborators of the administration (les collaborateurs bénévoles de l'administration). The notion sprang from the théorie de fonctionnaire de fait, (the theory of the civil servant in fact) which permits anyone voluntarily involved in emergency operations to be considered as a state agent. Today, it has undergone extensions that were not in perspective at the time it was conceived. This is a rundown of how the administration obtains the manpower that is vital to its mission. We would have stopped at this level had it not been for the emergence (re-emergence?) of an apparently new phenomenon. Cameroonians today especially those 
on the English-speaking side of the language divide are coming to terms with what may be called here "community" or "communal" labour in their cities. These expressions are apt to deceive and we use them interchangeably because we cannot find better ones. A community is a population aggregate inhabiting a contiguous territory, integrated through common experiences, possessing a number of common institutions, conscious of its unity, and able to act effectively in a crisis. In this regard, the community is a complex of activities which tie the inhabitants of an area into an interacting social group that works out its common life tasks in association. The population aggregate may range from a small tribal group to a modern metropolitan centre like Paris. The community usually organises itself to initiate non governmental activities that seek to promote and develop a richer community life or meet threats to its existence like floods, epidemics, fire etc.

It is in this context that the government has often welcome and assisted them and in several instances erected them into corporate bodies for the purpose. It usually develops from a grassroots movement void of coercion. That is how they come to organise communal labour to ensure the hygiene and sanitation of their environment. "Communal" is simply the adjective from community.

What takes place in Cameroon cities and more specifically those in the anglophone provinces is a bit different. It is first of all difficult to say that these city-dwellers necessarily form a community in the above sense of the word. While Cameroon tribal groups may pretend to be communities and to organise communal services though not being corporate bodies, there is no visible social cohesion in the cities. It is a mosaic of ethnic groups having in common only the modern administrative institutions in place even if a legal distinction is being made today between "indigenes" and "settlers" in the various Cameroon cities. It is therefore difficult to detect the "communal character" so to speak of the cities even if we use the expression community or communal labour. This having been said, the activities undertaken by the administrative authorities (not the grassroots) may one day develop a genuine communal undertaking. The reality is that institutions, structures and law hew patterns of behaviour and vice versa and this "communal character" in gestation would be more noticeable in the two anglophone provinces than in the rest of Cameroon.

In Bamenda, the headquarter of the anglophone North West Province, the day set aside for communal labour in the second Thursday of every month. As the day approaches, the administrative authorities make it a point of duty to have reminders broadcast on local radio stations that "clean-up campaign" or "keep Bamenda clean" day is closing in.

On the day itself, all commercial traffic by car or motorbike is interrupted from 8 a.m. to 12 p.m. All business premises are closed including the municipal market. All city dwellers are supposed to be cleaning around their homes. Roadside dwellers are supposed to extend their work to cover drainage, sewage disposal and repairs where the road needs these. 
Repairs in this regard signifies a little more than pushing some earth, stones and even household refuse at times into the deeper potholes. New garbage heaps surface on the roadsides that day to be carried away by the city services. There is martial calm and order throughout Bamenda and its suburbs. It is felt as far as Mile 4 Bamendankwe, Mile 6 Nkwen and Mile 8 in the approaches of Bafut. The police is on patrol. Too bad for anyone caught with his business open, a township taxi at work. This business is closed and the car or motorbike impounded. The fine may go up to sixty thousand (60.000) francs CFA. The person may be arraigned for breaching a prefectural order, which may fetch up to ten days imprisonment according to the penal code.

State employees during this period, perform but manual labour around their offices (at least for those who report there). The phenomenon is spanning the entire English-speaking Cameroon, starting from the villages closest to the leading cities. All traditional chiefs, quarterheads and ardos are called upon to co-operate to ensure the success of the exercise.

The clean-up campaign in the South West Province is a duplication of the same features but on the first Wednesday day of every month. It is at this price that anglophone cities are regularly rated the cleanest in the Republic. In as much as it is laudable, attention should not be shifted. The job of a jurist obligates us to verify the legality of this procedure of getting public work done. It would be neither too much nor the first time to question the lawfulness of an activity which unquestionably benefits the society in which it is undertaken. We resented and questioned the legality of colonial forced labour though it indisputably improved our lot. It is forced labour even when it is enacted by our own appointed or elected public authorities. Verifying the legality of forced labour is even more tempting today as we try to establish the rule of law in Cameroon. The Rule of Law as it is called in England, Rechtsstaat in Germany, Etat de droit in France and Due Process in the United States requires that all state acts be predicated on an existing rule. The notion originated from Germany in the nineteenth century as Rechtsstaat and was developed by German jurists and legal philosophers like von Mohl, Gneist, Jellinek etc. The English definition of the expression was given by A. V. Dicey: "It means in the first place, the absolute supremacy or predominance of regular law as opposed to the influence of arbitrary power and excludes the existence of arbitrariness, of prerogative or even of wide discretionary authority on the part of government. Englishmen are ruled by the law and by the law alone. A man may be punished for a breach of the law, but he can be punished for nothing else". If Carré de Malberg gives the notion a tentative definition in France, it is Claude Goyard who proposes a more concise one. He writes that it is a "state where the authorities, the administrative services, agents, from the summit to the base, in the order of authority abide by the law, in contrast to a system in which the authorities apply, do not apply or adapt the laws when they do exist, clear or inferred, to the convenience or to the circumstances, to say the least, following the judgement they think they can freely give to situations, ends and inter- 
ests - private or partisan interests which a priori are not illegal that they want to take into account".

The reality is that all the definitions have a common denominator - the principle of legality generally referred to as the principle of justice. Justice requires that all the decisions of public authorities be predicated on a law.

The Declaration of the Rights of Man and the Citizen of 1789 through which the non European world knew freedom in France was right on the mark when it specified in article 3. "The source of all sovereignty lies essentially in the nation. No corporation or individual may exercise any authority not expressly derived therefrom". Article 5 reinforced the point: "Statute law is entitled to forbid only actions harmful to society. What is not forbidden by the law may not be prohibited, and no one may be compelled to do that which it does not command". Professor Frede Castberg remarked that the content of this article is generally accepted as a constitutional principle all over the western world.

Cameroon, a country of western heritage is not an exception. The preamble of the constitution which is an integral part of the text states it clearly: "No one may be compelled to do what the law does not prescribe. No person may be prosecuted, arrested or detained except in the cases and according to the manner determined by law".

\section{The legal basis of the measure}

Those that support and enforce community labour invoke both the (A) texts and (B) context to back up the measure where it runs into difficulties of implementation.

\section{A. The texts}

Without the texts, the clean-up campaigns would probably never have existed to say the least as a State endeavour : "No person may be compelled to do what the law does not prescribe" says the preface of the 1996 constitution. The clean-up campaigns to be legal therefore have to be based on a text. They may be of (1) national or (2) international enactment.

\section{The texts of national enactment}

When we approached the Divisional Officer for Bamenda Central for the basis of the cleanup campaigns in that locality, he had only a circular letter signed by the Minister of Territorial administration on 4 April 2000 as the text on which the measure is predicated (a). If he 
showed a lot of reluctance to give us copies of the various orders declaring the second Thursday of the month clean-up days, we managed to obtain them elsewhere (b).

\section{a. The circular letter of 4 April 2000 by the Minister of Territorial Administration, a text or a pretext?}

The secular letter in question informed all the provincial governors, the Senior Divisional Officers, the Divisional Officers and District Heads all over the Republic that government attention has been drawn to the deterioration in the living conditions of people in both the urban and rural areas. It equally refers to the deterioration in the general appearance of the towns and rural areas which is all the more preoccupying because the administrative authorities, the mayors and the people themselves do not seem to worry about the disastrous consequences of this state of affairs on the health of the citizens and the image of the country. The circular continues to observe that the deteriorating situation has been observed to be due to:

- the unpatriotic an anarchical occupation of space by the population, notably the urban highways;

- the obstruction of roads and pavements by the random heaping and throwing away of various materials or by the development of informal activities;

- the rapid spread of makeshift motorparks on the main road or at major road junctions;

- he growth of slums and abandoned houses some of which are dilapidating or serve as hideouts for bandits and other criminals;

- he tendency for highway neighbourhood landowners to put up unauthorised structures;

- he neglect of wastelands and underdeveloped urban plots and

- hick bushes in the surrounding of houses and buildings housing administrative and private services.

Concerning the mayors specifically, the circular noted in condemnation that only few of them have been able to take initiatives to reverse the trend and re-establish good sanitary habits or public hygiene and sanitation habits. It took for proofs the fact that:

- cemeteries when they exist are not catered for;

- there is no permanent maintenance and rehabilitation of exiting road network;

- pipings or sewage systems to drain waste or rainwater are absent;

- existing gutters are never cleared;

- there is no co-ordination in the projects to develop networks (telephone, electricity, water, roads etc) and no concerted action among the actors involved;

- there are no road network plans in big towns; and

- generally a lack of coercive measures or alternative prescriptions, the implementation of which could circumvent the rampant want of good citizenship and disorder and restore discipline, cleanliness and the free movement of people and goods. 
The circular letter then set a two month time bar to remedy this situation and requested that the competent authorities implement certain priority measures in order to fight against slums, abandoned and dilapidating buildings. Mayors are therein instructed to take their full responsibility in line with the provisions of section 71 of Law $N^{\circ} 74 / 23$ of 5 December 1974 organising councils as concern council police powers. To this end, urgent measures were to be taken to;

- make an inventory of the slums, abandoned or dilapidating houses, notably along the main roads in towns and rural built-up areas;

- enjoin their owners in accordance with the law to either restore or demolish them within a maximum time-limit of two months;

- to cause each building to be demolished by the council in case the enjoining order is not respected at the end of the two months of grace.

It is further specified in the letter that these measures have to be implemented in concert and direct collaboration with the administrative authorities and that the police and the gendarmerie may be requisitioned for the purpose. The administrative authorities and mayors are further requested to take all measures aimed at causing all buildings, be they government services, private companies or homes bordering the highways;

- to be immediately renewed by painting of their walls and fences, and

- ensuring that their surroundings and the portion of the highway adjoining them are kept clean.

To deal with the anarchical occupation of spaces and the obstruction of roads and their sides, the minister asked each administrative and municipal authority to inform, sensitise and provide the people with civic and sanitary education. He specifically directs mayors and government delegates to take initiatives and double their efforts and ingenuity in the conception and implementation of measures that may promote:

- the preparation and development of unexploited public spaces;

- the setting up of parks and parking lots for transporters of people and goods in particular, and highway users in general;

- the periodic maintenance of wastelands and undeveloped urban plots by their owners;

- better protection of informal activities by the issuing of authorisations for temporary occupation of public spaces suitable for the activities and stating the minimum norms to be respected; and

- free movement of people and goods.

To maintain and sustain cleanliness in the towns, the minister, lauding the success that the national campaign on public hygiene and sanitation has recorded in the past, urged all administrative and municipal authorities to take the necessary measures to: 
- immediately set up a forum for concerted action involving the local services, the civil society and the local population in the daily quest for the improvement of living conditions of the people and the cleanliness of the towns and villages;

- sign in accordance with the laws and regulations, all police regulations capable of promoting hygiene, sanitation and environmental protection;

- relaunch with the assistance of councils and other partners, sanitation competition and officially award prizes therefore during public feast days and events;

- ensure that those who contravene the measures to be implemented in the purview of this circular letter are sanctioned notably on the basis of the offences provided for in section $362-\mathrm{R} 370$ of the penal code.

The circular further states that each administrative authority, mayor and government delegate should demonstrate commitment, conviction and firmness in the action to be carried out, get involved and involve the services placed under their responsibility through simple, realistic, rational and efficient work method in order to obtain concrete, tangible and durable results. Lastly, it calls for a report on the actions carried out, the results obtained and the difficulties encountered to be submitted to the Minister of Territorial Administration on a quarterly basis.

We do not hold this circular herein reproduced almost word for word, line after line to be the real text upon which the monthly clean-up campaign is predicated. Far from it, it looks more like a pretext because of the legal value Cameroon administrative law attaches to circular letters. Professor George Vedel made the following remark that in its trail defines a circular letter in French administrative law: "Any minister or head of a service exercises hierarchical authority over his subordinates which permits him to give them orders. These orders may have a general character and may in an abstract manner prescribe rules of conduct for the functioning of one part of the service or the order. They are either called 'circular' (letters) or 'service instructions"'.

The reality is that circular letters or service instructions are purely "internal" documents, restricted to the relation between the superior and his subordinate. Only occasionally do they amount to enforceable decisions (décisions exécutoires) or unilateral administrative acts creating rights and obligations with regard to citizens. Rarely are they decisions adversely affecting citizens (décisions faisant grief). The Conseil d'Etat in France stated the occasions where they may amount to veritable enforceable administrative decisions, in which respect, they may be contested before the juge administratif in the leading case of Institution Notre Dame de Kreisker. These were instances where:

- The minister under the guide of a service instruction in reality issues a decision that his subordinates have to implement. Such is not the case with the circular of 4 April 2000. The minister simply reminds his subordinates viz the provincial governors, the senior divisional officers, the divisional officers, and the district heads of existing legislation. 
His reference in the circular to the law organising councils relating to council policing powers and other laws and regulations indicates his concern for the respect of legality.

- The minister adds new requirements to those stated by the laws and regulations. Such again is not the case of the circular of 2000 which seems to indicate the prevailing problem in the cities and villages could be resolved by the solutions provided in the existing legal framework.

Even if it did add new requirements, this would amount to an enforceable decision only if a sanction were attached to it. We see that the circular letter refers only to existing sanctions - article 362 to R370 of the Cameroon penal code.

- The minister imposes new obligations on or provides new safeguards for the citizens. Once more, this is not the case with the circular of 4 April 2000.

This circular is simply interpretative of existing legislation and nothing more. It can neither be invoked to back up an administrative decision nor be contested before the administrative bench of the supreme court which is the juge administratif or administrative court in Cameroon. It is a "non decision", so to speak. As a dependable text on which our clean-up campaigns are based, it fails.

\section{b. The prefectural orders organising communal labour}

The powers and duties of the heads of the administrative units in the Republic of Cameroon are defined by Decree $N^{\circ} 78 / 485$ of 9 November 1978 to lay down the powers and duties of the administrative units and the bodies and officials responsible for assisting them in the performance of their duties. These authorities participate in the exercise of what is known in French constitutional and administrative law as the pouvoir réglementaire (regulatory rules and orders), the prerogative of the executive power. The decisions of these provincial authorities take the form of "orders" (arrêtés). Hence, there are gubernatorial and prefectural orders in the hierarchy of laws in Cameroon. A typical executive or administrative decision in Cameroon law is preceded by a presentation of the authority ruling, an enumeration of the legal grounds, the procedure and even the circumstances backing his decision. These formalities make up what is called the visa (visa) in the study of the forms and procedures of administrative activity.

For unstated reasons, the Divisional Officers to enact the clean-up campaigns prefer to proceed by what they themselves style "announcements", which is a kind of novelty. It is limited to a simple communiqué signed and forwarded for broadcast on local radio stations "as many times as possible". The "announcement" which has become standard today and renewed on a monthly basis as the day approaches laconically "reminds the population of Bamenda that the monthly clean-up campaign resumes its work on Thursday...The usual measures shall be observed to ensure the effectiveness of work to be carried out by the population". 
It is true the adoption of the form "announcement" does not vitiate the decision. Administrative decisions may take many other informal shapes. A light signal for example is an administrative order. It may also be verbalor even implied. It is also true the non quotation of the visa or legal basis of the "announcement" is not a vitiating defect. In fact, the French Conseil d'Etat held in Dame Nandon that "the absence of references to the texts by virtue of which an administrative act was legally signed does not amount to an illegality of a magnitude to justify the annulment of the act".

No more vitiating can be an erroneous visa if the decision itself is legally grounded. The same administrative supreme court in this regard ruled in Veuve Robince de Plas: "considering on the other hand, that it is clear from the file that the order challenged was signed further to the implementation of the law of 1 March 1942; That the public notice bearing a copy of the said order and pasted on Dame Robince de Plas's wall erroneously cited the law of 11 October 1940, repealed by the law of 1 March 1942 is without effect on the legality of the said order".

We are left with the question if the administrative authorities have the power to organise community law, a practice that has gone on for seven years today unchallenged. It is so impossible to invoke the decree of 9 November 1978 laying down the powers and duties of the heads of administrative units to back the activity to a point where the feeling that the non quotation of the visa is deliberate cannot be restrained. Basing the act on that text would apparently have brought the glow of spotlight embarrassingly on the illegality. The adoption of the form of an announcement ostensibly distances the administration from an activity that may likely one day raise a legal problem especially at a time when the citizenry is increasingly becoming aware of their rights and obligations. That is probably why some administrative authorities at times strain to prove it is an activity of popular initiative even when the role of constraint is evident in it success.

\section{Texts of international enactment}

The institution of communal labour may be defensible by international instruments. Those that denounce it brand it forced labour. How do you avoid being assailed by this widespread feeling against the backdrop of a collective memory deeply scarred by the largescale resort to forced labour by the Germans, the British and the French that accompanied us to independence? Yes, community work is forced, involuntary or compulsory labour. The Dutch scholar, W. Kloosboer, in the introduction to her comprehensive study, Involuntary Labour since the Abolition of Slavery thus defined forced labour: "We will term that labour compulsory from which the labourer cannot withdraw if he so wishes without being liable to punishment and/or for which he has been accepted without his willing consent. The motive for the imposition of this labour must moreover be to gain profit or have profit gained". The International Labour Organisation (ILO) since its creation has been concerned 
with the problems of forced labour and to this effect has passed two conventions, in 1930 and 1957 outlawing resort to it. In the 1930 convention $\mathrm{N}^{\circ} 9$, it defined forced or compulsory labour as "all work or service which is exacted from any person under the menace of any penalty and for which the said person has not offered himself voluntarily". However, excluded from the category of forced labour among others are, "minor communal services" and work in the case of force majeure. "Force majeure" relates to work exacted "in the event of war or of a calamity or threatened calamity, such as fire, flood, famine, earthquake, violent epidemic or epizootic diseases, invasion by animal, insect or vegetable pests and in general any circumstances that would endanger the existence or well-being of the whole or part of the population".

It is within the bounds of reasonable presumptions that forced labour is also legally justifiable in international law where it is exacted from criminals following a fair trial.

That communal labour as it is enforced in Cameroon amounts to forced labour or is just "minor communal services" is something to be left to the determination of the competent international body or the courts especially the administrative bench of the supreme court. That it is a measure to meet a force majeure or not can only be determined after a close examination of the context invoked to justify the practice.

It is only after this that the State of Cameroon may escape condemnation for breach of its international obligations. Forced labour is also condemned by international instruments ratified by the Republic of Cameroon. Nevertheless, the situation has never received appreciable limelight as regards Cameroon where the context is also being invoked at the heels of the texts to justify it.

\section{B. The context}

We cannot explain the practice of communal labour without examining the general circumstances in which the administrative authorities resorted to it. These circumstances having little to do with the law which should take the development of emergencies into account at the time it is being adopted. This is one of the strongest criticisms levelled against the law and jurists as well. Professor Jean Dabin in a speech acknowledging the presentation of a mélanges as a tribute to him at the Université de Louvain in Belgium said that "the job of a jurist today is being decried enough, even in intellectual quarters, even in higher learning circles. He is being reproached not only for not feeding his man...but also of playing a redundant, disturbing and almost parasitical role in the society. Legalism that is faultfinding with texts, obstructing in its categories, removed from realities is being taken to task. Does the future not depend on science and in the domain of the human sciences to psychology, economics and sociology?" The history of the development of the law abounds with 
instances where legislation was outrun by events, especially crisis. Montesquieu wrote in l'esprit des lois that laws should never be made without taking the surrounding circumstances into account. But the dilemma is that there have been and will always be contexts ahead of the text. Cameroon is not spared what is definitely a nightmarish inevitability. In this regard, at least three major extra legal factors have to be reckoned with before a final opinion is taken on the emergence of the phenomenon of communal labour: (1) the withdrawal of the state from priority areas due to the prevalent severe economic crisis (2) corruption and (3) the community spirit peculiar to anglophone societies, both strong reasons to withhold judgement on the issue.

\section{The withdrawal of the state from priority areas due to the severe economic crisis}

The deterioration of the road infrastructure, hygiene and sanitation and the general appearance of our cities and villages are unquestionably the results of one of the severest socioeconomic crisis the nation ever experienced since independence. After holding out for a long time, the country finally welcome assistance from the International Monetary fund in the 1990s with a draconian structural adjustment programme in its train. To meet the challenge and put up with servicing its phenomenal national debt, the state had to withdraw from its traditional priority functions. In 1999, Béatrice Hibou spoke of "the flourish of arguments on the 'withdrawal', the 'helplessness' or the 'collapse' of the state" in the African countries in general. The sorry state of our townships and villages is simply one of the expressions of this "withdrawal" of the state. In a leading report in the Paris-based magazine, Jeune Afrique Economie, Gilbert Tchoumba who entitles it Le scandale Douala (Douala the scandal) paints a stupefying portrait of the economic capital, Douala - disgracefully unmaintained roads, poor disposal of sewage, poor drainage, random disposal of household and industrial waste, widespread littering and excretal pollution etc. An incumbent mayor is quoted in it to have likened the city to a war zone. He remarks that the same evidence of neglect is perceptible in the country's other leading cities and warns of the possibility of the outbreak of epidemics. The State earlier resorted to the privatisation of the basic services where this was possible. It equally gave its blessing to communal initiative where there need was immediate and the citizenry ready to act. This was mostly in the domain of security: "organise self-defence groups and vigilance committees in the neighbourhoods under the auspices of the competent administrative authorities," the Minister of Territorial Administration told the inhabitants of Douala city during the installation of the new governor of the Littoral province on 31 May 2001. The reality is that the forces of law and order are no longer able to ensure the security of persons and property. Citizens can respond quicker when the call is to ensure their own security because the pinch is more immediately felt. But to rally them to maintain roads, hygiene and sanitation with the same spontaneity is more difficult. The awareness of the citizens in this domain is apparently low. It definitely would take more than an appeal to the 'community spirit' to clean up our towns. The reference in the "announcement" to "those who can kick against the success of 
the operation" is revealing. It would require a more energetic approach and the law falls short in this respect. The reality is that the good administrative officer would not allow the sore to keep on festering because the law is unreliable. Professor Emile Giraud remarked that "the aim of the administration is to obtain a result, not to obey the laws and regulations in force. Perfectly law-abiding administrators may be mediocre if they have a poor judgement, lack initiative, are clumsy or unskilful. It is a defect for an administrator to be narrowly law-minded. He thus forgets his role. He is first and foremost concerned with performing the rituals and formalities which by themselves are useless correctly and hence, misses the useful result he has to aim at obtaining". Professor André Mathiot on his part wrote that if for the respect of principles, the interruption of the public services were admitted, the state would be condemned to death." Prime Minister Aristide Briand was saying almost the same thing but in other words when he told the French parliament on 29 October 1910: "If in the face of an eventuality that may endanger the fatherland the government did not find a way of defending the existence of the nation, if it had to resort to illegality, it will do it". Community labour may be said to be one of those illegalities for public interest. Such may well be the intimate conviction of the minister when he exhorted the heads of the administrative units to "show proof of initiative and redouble their zeal and ingenuity ... in the conception and implementation of measures...".

\section{Corruption}

It is perfectly true that the difficulty in mobilising volunteers to maintain the roads, hygiene and sanitation in our cities and villages is not as successful as in the other domains like security because of the widespread feeling that public funds saved by community labour will simply be looted by corrupt officials. The problem of corruption in Cameroon is so obvious that no more than a general reference is required to be believed. There however are still patriotic citizens that separate their country from their leaders. Love for the fatherland may at times be different from love of its leadership. This segment of the population prefers to side-step the authorities and get the work done by themselves. They are eager not to be victims of not only corruption but also of the duplication of structures. If they have to wait for the conflict of jurisdiction among the various ministries, (Territorial Administration, Urban Affairs and Townplanning) and the various administrative structures (the appointed government delegates and elected mayors) to be resolved, the sore may fester beyond remedy. The more reasonable thing to do is to get directly involved in the protection of public weal. When they do not do this through communal labour, (even if the prod comes again from the administration), they directly monitor the rendering of goods and services of general interest. To explain the sorry state of our roads, a former mayor and member of parliament told Gilbert Toumba: "When a businessman wins a public contract bribes are heavy, at times heavier than the amount the 'official' contract itself is worth. He can therefore only make it up by reducing the thickness of the tar". This explains the recent appearance of consumer organisations in Cameroon. In The Organisation of Consumer Sover- 
eignty (OCOSO) vs. Ets. Ndifor and Bros., the plaintiff, an organisation for the defence of consumers complained to the court that not only did the defendant, a party to a government public works contract fail to perform the said contract within the stated time lines but also did the job so poorly that "the Bamenda population and targeted consumers of this budgetary allocation were cheated and disgrace equally brought to bear on them by the awful look of this road junction vis-vis any tourist entering the town". In fact, not up to three months after the repairs, the road junction fell into "more deplorable state of disrepair than it was before the contract was awarded".

Communal labour therefore in a way is an expression of the collapse of trust in the public authorities and the ambition to self-reliance as a means of survival.

\section{The 'community spirit' peculiar to anglophone societies}

Communal labour for all that has been said is apparently an anglophone specificity if not an anglophone interpretation of the 4 April 2000 ministerial circular. Proof of it is that while the text invoked remained the same, it is only in anglophone Cameroon that the clean-up campaign is observed, the idea having failed elsewhere in the country because of indifference if not outright hostility. If it is true communal labour existed in traditional African societies, it is also seemingly part of the British heritage. By the old common law of England, every parish had to perform street services. The vestrymen of the parish appointed a surveyor of highways every year, whose duty it was to see that everyman in the parish either helped to repair the roads or paid a find for not helping. This law was often ignored and in any case, "repair" the streets came to mean a little more than pushing some earth, stones and household refuse into the deeper potholes in a road. In bigger towns, the pathways of cobblestones which ran down the middle of some streets were often repaired with stones stolen from a ruined church, castle or townwall. The anglophone part of the Republic of Cameroon which out of defiance at times refers to the rest of country la République $d u$ Cameroun has often laid claim to a cultural difference. The us-against-them mentality has been reinforced by the alleged discrimination against them and the fear of a real or apparent policy of francophonisation by the dominantly francophone ruling élite. The phenomenon of effective communal labour seems to be part of this communal spirit. Let's not perish because the regime would not come to our aid, the reasoning seems to run. Community labour is not an anglophone Cameroon prerogative. We find it in Nigeria where it is called Sanitation Day. It used to be Cleaning Day in Sierra Leone and Community Labour in Liberia just to limit ourselves to these few. Apparently, it is a practice revived from times gone by. If this be true, the 4 April 2000 circular was nothing more than a pretext. This does not make the practice legal. Communal labour remains a challenge to the rule of law despite its positive effects. It remains a source of grievance to many citydwellers. The modalities of its implementation will complete their desolation 


\section{The modalities of its application}

In law, the illegality of a principle may never be justified by the way it is implemented. At most, the implementation of the measure may procure some mitigation of the sanction to be inflicted just as it may aggravate the illegality on the one hand.

On the other hand, a measure even when it is legal may develop illegalities in its implementation. A citizen who defies a legal requisition order for example has to be prosecuted and only in exceptional circumstances may force be deployed to obtain compliance. By the same token, if the administrative court in Cameroon one day upholds the legality of the clean-up campaigns, it may reverse its position concerning the way they are carried out. The prefectural "announcement" of the clean-up campaigns usually ends with " The usual measures shall be observed to ensure the effectiveness of the work to be carried out by the population". No text spells out "the usual measures" that have become a regular fixture in the "announcement". However, the constitution of "mix control teams" to supervise the operation seems to suggest an awareness on the part of the administration of the possibility of excesses. Two major illegalities may flaw the implementation of the operation: (A) inequalities and (B) the absence of rules concerning administrative liability.

\section{A. Inequalities}

The management of the clean-up campaigns has developed a feeling in some quarters that the principles governing it respect persons. All persons and regions apparently stand in the same relation to the privilege of being spared the constraints of communal labour. It is therefore neither lawful nor reasonable to exclude from this favour (1) certain social categories and (2) certain regions that do not need the exercise less than the others.

\section{Inequality in the treatment of social categories}

The law whether it protects or punishes must be the same for all. Since all citizens are equal in its eyes...," states the Declaration of 1789. The preface of the 1996 constitution inherited this provision of the Declaration in other words: "All persons shall have equal rights and duties".

The mission entrusted to the "mix control teams" constituted on clean-up days is to "track down all those who can kick against the success of the operation notably benskin men, transporters, taximen etc". It is first of all curious that what can rightfully be termed in Cameroon administrative law, a unilateral administrative act of general character (acte réglementaire) should target particular social groups in its implementation. Even if experience indicates they have been noted for breaching the law (in question), it is to say the 
least, impudent and even unprofessional to single them out in a unilateral administrative act of general character. Deference to public sensibilities in the drafting of the texts that govern us is the issue here even when such texts do not strike protestations from the trade unions that protect the interests of these social categories.

Then more important is the suspicion hovering around the substance of the targeted groups. The "benskin men", transporters (if the inter-urban transport companies are excluded), seem to be the part of what can be referred to as the modest earners in the cities. Transportation is an activity of high visibility and that is what makes them differ from the other members of their class.

A standstill in all township activity even if it lasts only till noon affects them most, for they live from hand to mouth so to speak and some of them even work only in shifts and are paid accordingly. The temptation to violate the clean-up campaign therefore beckons more insistently to them. This is the first cause of a reservation towards the clean-up campaigns.

The second one stems from the feeling that they are singled out because they are easy targets with their usually modest intellectual firepower. This ensures that the measure adversely affecting them will scarcely wind up in a court of law. The administration is more careful when it comes to dealing with the motoring élite who would probably not exercise patience with the harassments of the operation for a long time. They are more aware of the difference between legality and illegality and know where to complain. They have won lawsuits against the administration, obtained payment for damages incurred and even the removal of officials that trespassed against them by petitioning the superiors. The reality is that business can be conducted with the private cars that are allowed to cruise freely in the townships on clean-up days. The owners of these private cars offend against the operation as much as any other offenders. A man driving around in his private car is not participating in keeping his environment neat like a benskin man picking up commuters.

The impression is that the law favours the powerful. It should have been applied to all equally though the question of the situation of a city-dweller whose environment is neat rears its head.

\section{Inequality in the treatment of regions}

Article 1 (2) of the Cameroon constitution provides that the "Republic of Cameroon shall be a decentralised unitary state" and that "It shall be one and indivisible".

More important, article 2(1) states that national sovereignty shall be vested in the people of Cameroon who shall exercise same either through the President of the Republic and mem- 
bers of parliament or by way of referendum. No section of the people or any individual shall arrogate to itself or himself the exercise thereof".

This is another heritage of the French Revolution, more specifically of article 3 of the Declaration of 1789. The word "sovereignty is specifically of French origin and it has no equivalent in any other language. It means total independence in the behaviour of a political entity on the external plane, and total superiority over all other political forces on the internal plane. L'Abbé Sieyès, addressing the constituent assembly on 7 September 1789 dispelled all illusions in this regard when he said France "should not become a federal state, made up of several Republics, united by whatever type of political bond. France is and must remain one whole, placed in all its parts under one law and a common administration". He was in fact talking of the theory of national sovereignty here. One of the notable extensions of this theory is that "The law is the expression of the general will" (la loi est l'expression de la volonté générale). This means that the law being an act of sovereignty applies to the entire nation equally, even to those that voted against it. It is the entire nation not a fraction thereof that has spoken.

The Cameroon constitution of 4 March 1960 adopted this conception of national sovereignty and indivisibility. The 1961 federal constitution inherited it curiously enough. The reality is that the theory of national sovereignty has no place in a federal system for federal authority stops where state authority begins and vice versa. The sovereignty of the federation is counterbalanced by the sovereignty of the states. The exclusion of the notion of the indivisibility of the Republic (which is an accessory of national sovereignty) from the federal constitution is clearly a sign of the times.

The abandonment of the federal system in 1972 in favour of the unitary system was a total reversion to the theory. Indivisibility, an extension of the theory regained its place in the text and by a law of February 1984, the nation dropped its name, the "United Republic of Cameroon" and reverted to its appellation of 1960, the Republic of Cameroon. For good measure, the constitution outlawed any imposed mandate. All our elected officials speak in the name of the entire nation. Their acts have the force of the general will. The question now is how a ministerial circular of 4 April 2000, supposedly an expression of the general will should take a specific interpretation and implementation in some of the provinces. The institutionalisation of the clean up campaigns is an interpretation of the 4 April 2000 ministerial circular that is peculiar to the English-speaking provinces of the Republic. More sacrifice is being exacted by the public authorities in these regions. Are we not by this precedence granting the right to interpret our national laws that hold the nation together to the various regions? Already, the feeling that they are different from the other regions is taking root on the English-speaking side of the national divide. Communal labour if its legality be proven one day has to be nation-wide or be considered a non-governmental undertaking. The involvement of the administrative authorities prompts the suspicion that 
the budget for hygiene and sanitation may one day be reduced because of this popular endeavour. Already, the responsibility for preparing the cities for public manifestations seems to be shifting to the citizens in these regions.

\section{B. The absence of guarantees}

Ever since the rule of law began to set in to temper the excesses of state sovereignty, the relation between the state or the administration and the citizenry has become a carefully balanced compensatory mechanism. Drafters of administrative decisions began to pay attention not only to requirements for the success of administrative operations but also to lessening the toll of the activity on the citizenry. In fact, this has become the yardstick to identify good from bad legislation. Halleys-Debot, commenting one of the decisions of the Conseil d'Etat in France could not be clearer: "The first merit of a good law is supposed precisely to be that no prejudice no matter how light, remain uncompensated for and no grievance without a court" The resort to the clause exorbitante du droit commun by the administration was counterbalanced by the principle of administrative responsibility, both contractual and non contractual. A tributary of this development is the principle of the equality of all citizens in the face of public burdens stated in the 1789 Declaration. Professor Jean Rivero once paid tribute to the guarantees against abuse offered to citizens by the napoleonic administrative acts and decried the loss of this commitment to the protection of the citizen in present day administrative acts in France. The decisions announcing and enacting communal labour in the anglophone provinces partake of the latter mind-set. None of them makes mention, talk less of laying down rules governing the responsibility of the administration with regards to communal labour.

This problem thus left in the hands of the courts does not completely resolve the problem of guarantees to the citizens participating in it. While we do not have any records of claims related to communal labour and brought before the courts, french case-law suggests citizens involved in it may be treated as administrative volunteers (les collaborateurs bénévoles de l'administration) (1) or (2) labour conscripts (les requis) which only half resolves the problem.

\section{Ranking them as volunteers of the administration (les collaborateurs bénévoles de l'administration), an undependable remedy}

A volunteer in military law is one who freely and voluntarily offers himself for service in the army or navy as distinguished from one who is compelled to serve by draft or conscription, and also from one entered by enlistment in the standing army. In French administrative law, it is one who freely and voluntarily offers himself for service in the administration as distinguished from one who is compelled to serve by an act of recruitment or requisition. 
Professor Jean-François Prévost defined a collaborateur bénévole as « one who acts costfree, obtaining neither compensation for his action, nor any kind of payment, of course besides cases where he suffered a prejudice (but in this regard, this payment is effected for the prejudice suffered and not for the activity carried out)". An example is a selfless citizen who joins a gendarme officer in persuing a criminal. Members of the city council in Evian (Switzerland) admitted a hotel owner who received journalists on the occasion of the holding of an important political conference in the city was a volunteer of the administration. Some of the citizens that are active in the clean-up campaigns regularly organised in Cameroon cities may comfortably fit into this category of state agents. It is worth pointing out that the French administrative law which we follow used to be hostile towards the intrusion of these collaborateurs bénévoles in the management of public services. For quite some time, they never found more favour with the administrative judge, bar instances where their involvement was solicited. Since 1953, however, the administrative courts have gone a long way to reverse their attitude towards them. Today, a kick-off in a regatta is held to be an activity of public interest for which damages may be awarded where a loss was incurred. Training for the activity itself may be rated as such, just as sawing wood to provide heating in a school. This compensation for prejudice borne may even be extended to citizens whose spontaneous intervention was unbeknown to the administrative authorities.

We owe this development in favour of the volunteer (even if it stops short of procuring remuneration for services rendered) exclusively to the administrative courts. A volunteer has no status in law. If the state encourages voluntary popular involvement in activities of general interest, the aim of it all is to save our meagre public funds. Logically, providing guarantees to those involved or lending support to the present attitude of the courts simply boils down to desiring something and its opposite at the same time. In as much as a hearing is being given to victims of voluntary involvement, there is a strong movement for the tightening of the screws. The excessive generosity of the administrative court is an escalating justification. In La Commune de Batz-Sur-Mer c/ Dame Veuve Tesson, for example, the court awarded damages to the tune of four hundred and fifty thousand (450.000) French francs when the council budget from which it was to be paid was scarcely up to five hundred and fifty thousand (550.000) French francs. The disturbing and correspondingly expanding reflex of the administration to ignore the fines is a unit of measure of the dilemma. Perhaps a better solution would be to resort to administrative redress where the so-called volunteer worker sustained a loss. We all know under this scenario, the administration will be judge and suitor at the same time. Whether it gladdens or saddens, the helmet of a volunteer communal labourer is not the safest. That is why some have shifted options to legally rank them as labour conscripts, which the problem only partially resolved. 


\section{Ranking them as labour conscripts, a half measure}

The law of 15 July 1968 to organise the system of requisitions defines a labour conscript (un requis) as "a natural person or corporate body from whom the performance of certain services has been exacted by an act of public authority under conditions strictly defined by the law".

The administrative authorities before promulgating the organisation of monthly communal labour were aware of the technique of requisition or impressment as a way of obtaining the manpower required for the success of their mission. The reality is that the guarantee in favour of the citizen contained in the 1968 law (precise conditions of resort to it, the equality of all citizens with regards to it, adequate compensation, the existence of administrative and judicial means of redress, etc.) are more than they can ignore. Yet, the text equally opens enticing possibilities to ensure efficiency in such administrative operations. In fact, the authorities vested with the right of requisition may expect certain collective services of short duration to be supplied without compensation and severe penalties may be enacted against defaulters.

What prompts public authorities to shun this text, (the requirement that it be resorted to only "under conditions strictly defined by the law") is exactly what incites or what should incite citizens to invoke it where the question of their status arises. Strictly- speaking, their participation in communal labour does not raise them to labour conscripts. The conditions for the resort to this formidable legislative arsenal are simply not fulfilled (a decree declaring a state of alert, emergency, partial or total mobilisation, a state of siege etc).

However, the administrative judge once more has been making ouvertures towards those involved in the operation that may find the status of labour conscripts more attractive.. Today, the solicitation of popular involvement in activities of general interest by the administrative authorities may readily be assimilated to an order of requisition even when it is verbal. In fact, status of labour conscripts may be given where administrative officials, the traditional custodians of public weal never even featured in the relation between the citizen and the activity. The order of requisition may not be formal hence, it may be requisition where the citizen stepped in not at the behest of the administration, but at the invitation of his fellow citizens authorised by the public authorities. With these developments, to take citizens mobilised for communal labour by the administration (which is our case) as labour conscripts a conclusion that may be adopted without too much hesitation. Here again however, we are to meet some of the hurdles already encountered in the attempt to rank them as volunteers. It would not be easy to get the administration apparently bent on dodging the resort to formal requisition to accept it. With the administrative judge insisting on the difference between labour conscripts and solicited participation in carrying out administrative tasks, the citizen may be denied this very coveted status in the organisation 
of communal labour. This is to say that whether they style them volunteers or labour conscripts, a legal vacuum is beckoning to them.

\section{Conclusion}

We come to the opinion that either way it goes, great injustice may result. Apparently overwhelmed by the exponential multiplication of public responsibilities engendered by the shift from the traditional to the modern state, the authorities that are custodians of common weal are reaching out for offers from men and women of good will. Now it is time to appeal for solidarity and self-reliance within the various communities. This is laudable. It is even African. Everyman is the keeper of his brother. Suspicion by the volunteer or labour conscript that the prompter of the gesture would shy away and leave him to his own devices if he suffers a loss in the process undermines credibility. If the law today welcomes popular participation in the discharge of public duties, if public interest is to become the law of the land because the state is staggering under its burden, it should at least provide a minimum of guarantee for citizens ready for popular effort. Being the carer and the carer of the carer at the same time should be seen as too much of a sacrifice if the state that is supposed to superintend these activities is bent on seeing things done. The temptation is to believe all is well since the administrative judge is not failing these risk bearers: "case-law on occasional collaborators of the public service, today rich and well-known, constitutes a coherent and complete theory even if it has not yet attained its final completion point" wrote M.-B. Cheramy. Those who fall to this reasoning may score only half the point.

First of all, there are signs that opposition is developing against the position of the administrative judge as we have earlier seen. Secondly, we must ask ourselves if the administrative courts in conceiving and developing the notions discussed above have not overstepped their authority at a time when they are increasingly being suspected of "policy-making" under the colour of adjudication. The role of the judge is to apply the law, only the law, and nothing but the law. If community self-reliance and solidarity are values to be encouraged, why should the lawmaker or the executive not codify the status of those involved ? In France, the law of 3 March 1822 and the decree of 4 January 1896 empowers sanitation officials to requisition citizens in an emergency. It is incumbent on the administrative authorities to take the first step in this direction if we are to follow suite. It suffices that they table the suggestion to the hierarchy which already indicates it would welcome steps to bring about efficiency in the operation. The ministerial circular of 4 April 2000 flashes the green light: "A report on the actions carried out, the results obtained, and the difficulties encountered, if any, should be addressed to me quarterly, because the government attaches great importance to this operation...". 
Let us hope the recent appearance of spades, cutlasses, hoes, first aid boxes, etc among office equipment in the drawing up of the budget of certain administrative services heralds the beginning of general rules and regulations governing communal labour. 